\title{
The Study of Self-Assessed Health between the Elderly People of Shiraz and Yasuj, Iran, Case study men elderly over 65 years old
}

\author{
Movahedmajd $M^{*}$, Jahanbazian $S^{2}$, Panahi $S^{3}$
}

\begin{abstract}
Introduction and purpose: The elderly population is increasing and the situation of this age group to improve their health and prevention of diseases is necessary. The aim of this study was assessed the health among elderly men living in Shiraz and Yasuj cities.

Materials and Methods: This cross-sectional descriptive and analytical study was conducted in 2015. To collect data, 380 elderly men in Shiraz and Yasuj were selected via random clustering sampling method and information was collected using 7-dimension standard questionnaire. Data analysis was conducted using SPSS statistical software version 20 at levels of descriptive and inferential statistics.

Findings:The mean of four dimensions of the elderly health for the study was $77.07 \pm$ 15.03.Determination coefficient R2 statistics also show that $25.8 \%$ of the health self-assessment variations were explained by three independent variables remaining in the equation, including selfesteem, health behaviors and medical history. Variables such as age, education and medical history class identity were significantly associated with health self-assessment.

Conclusion: knowing the status in the health of a community of people who are planning to have its future society will help in reasonable estimates. One of the important objectives of the health system in each country is to protect the health of all people in the community. For this, all aspects of health, physical, mental and social life need to be taken into consideration in all stages of life. Health is not just a biological, and social factors are also involved in determining the health of people.
\end{abstract}

Keywords: self-assessment of health, elderly, self-esteem, social support, communication with childr

Copyright $(02018$ Quarterly Journal of Geriatric Nursing.This is an open-access article distributed under the terms of the Creative Commons Attribution international 4.0 International License(http://creativecommons.org/licenses/by /4.0/) which permits copy and redistribute the material, in any medium or format, provided the original work is properly cited.

1 - Faculty of economic, Management and social science, Shiraz university, Shiraz, Iran

(Corresponding Author):E-mail:: mmovahed@ rose.shirazu.ac.ir

2 - MSc. Student of demographics, Shiraz University, Shiraz, Iran

3 - MSc. Student of sociology,Tarbiat Modares University, Tehran, Iran 


\title{
بررسى خودارزيابى سلامت سالمندان مرد شهرهاى شيراز و ياسوج
}

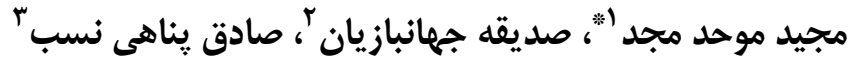

تاريخ دريافت مقاله: سז/ع / هوسا

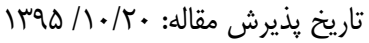

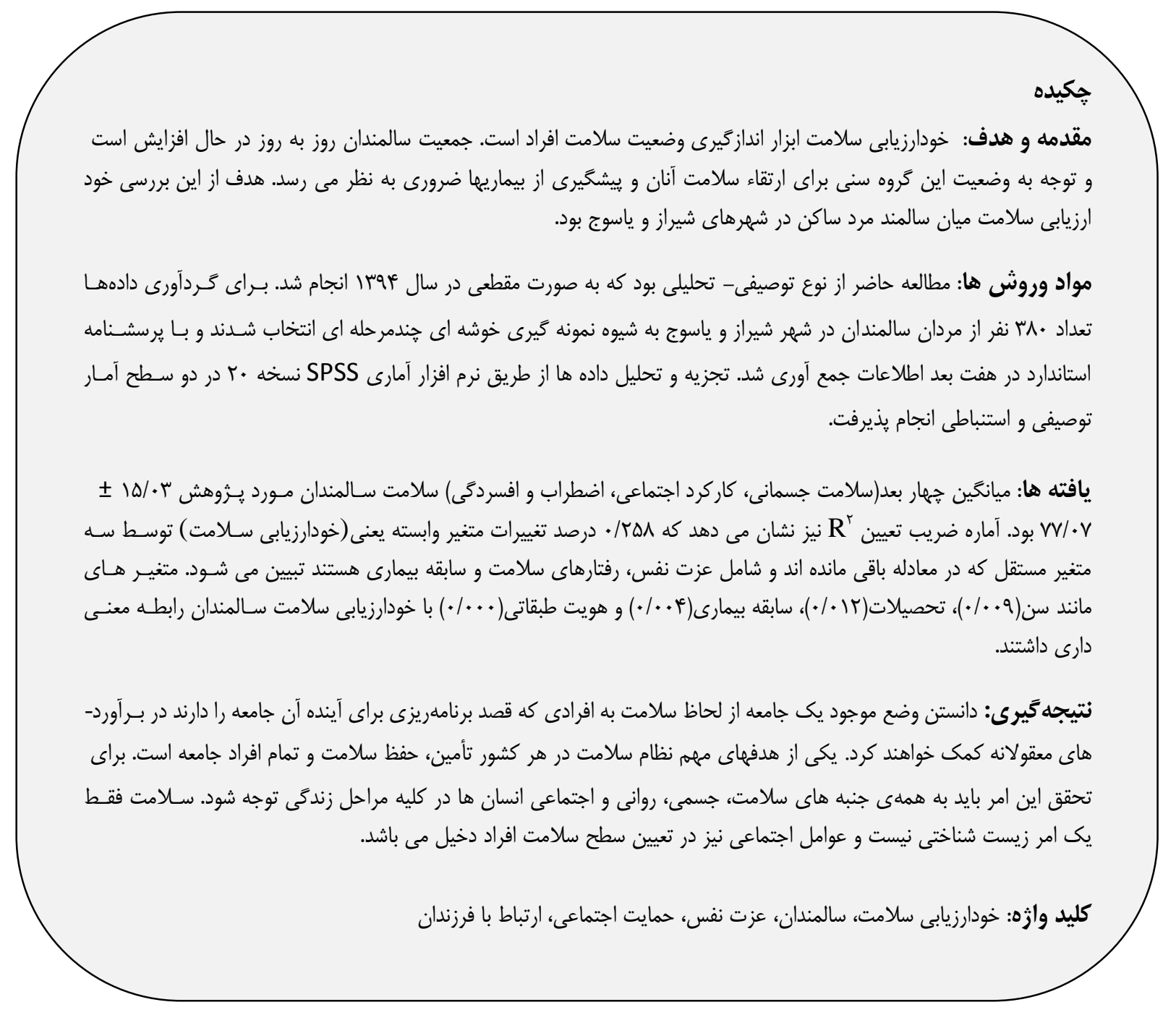

ا- دانشكده اقتصاد، مديريت و علوم اجتماعى، دانشكاه شيراز، شيراز، ايران

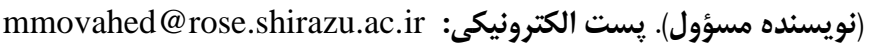
r- دانشجوى كارشناسى ارشد جمعيت شناسى ، دانشكده اقتصاد، مديريت و علوم اجتماعى، دانشگاه شيراز، شيراز، ايران

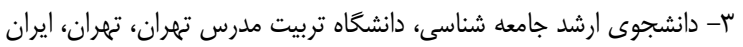

1. 


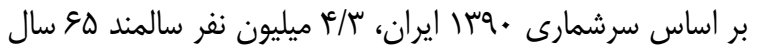

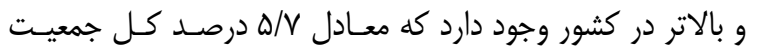
ايران است. بر اساس ييش بينىهاى جمعيتى تا سال • بها تعـداد سالمندان ه هال و بالاتر ايران به \| ميليون نفر افزايش مىيابد و سهم جمعيتى انها به حدود • ץ درصد خواهد رسـيد[ه]. در حسال حاضر نرخ رشد جمعيت در كشور مـا \&/ا درصــ اســـ و ايـن در حالى است كه نرخ رشد جمعيـت سـالمندى ه/ץ درصـد اســ[؟]. يديده سالمندى در كشور ما هنوز به عنـوان يـك يديــه ضـرورى مورد توجه قرار نغرفته است. اما اين واقعيت وجود دارد كه جمعيت سالمندان با رشدى بيشتر از رشد كل جمعيت رو به افزايش اسـت. در واقع همراه با رشــــــمعيــ و افـزايش اميـــــــــــــــى سـير سالمندى روند صعودى دارد و ضعف و ناتوانى اين گروه مراقبتها و توجهات ويزه اى را مى طلبد. افزايش نرخ رشد جمعيت سالمند بـر ضرورت توجه به وضعيت سلامت اين گروه از جامعه مىافزايد. در مورد ضرورت و اهميت اين يزوهش بايد كفت كه ازدياد سالمندان باعث افزايش توجه به مبحث سلامت در بين سالمندان شده است و بايد به هملى جنبههاى حياتى در سـامت سـالمندان از جملـهـ سلامت اجتماعى، روانى، جسمانى و معنوى توجه كـرد. از آنجـايى كه سالخوردگى فرايندى همخَانى اسـت و در كـل دوران زنـــى ادامه دارد، آماده ساختن كل جمعيـت بــراى دوران سـالخوردگى و توجه به سلامت آنها بايد جنبهى تفكيك نإِـير از سياسـتهـاى توسعه اقتصادى - اجتماعى باشد و با مسـاعى زيـادى در كليـه ى سطوح كشورى، محلى، خـانوادگى و فـردى تـوام گـردد شـيوهى برخورد با اين مسئله نيز بايد جامع و توسعهايى باشد[V].
سالمندى دوران حساسى از زندگى بشر است كه طى آن سالمندان در معرض تهلديدات بالقوه اى نظير افـزايش ابـتلا بـهـ بيماريهـاى مزمن، تنهايى و انزوا و عدم برخوردارى از حمايت اجتماعى بوده و به دليل ناتوانى هاى جسمى و ذهنـى، در مـوارد زيـادى اسـتقلال فرديشان مورد تهديد قرار مى گيرد. از سـويى بـا افـزايش جمعيـت

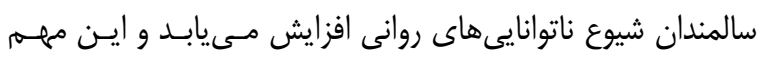
سيستمهاى مراقبتى، بهداشتى و اجتماعى را كه هم اكنـون تحـت فشارهاى مادى هستند، نخران ساخته است[ []. سلامتى يك روند يويا است و با كذشت زمان مفهوم آن تغيير خواهد كرد براى افراد مختلف نيز معانى گَوناگونى دارد و حتى يكى فـرد هـم در طـول زندگى خود ممكـن اسـت تعـاريف مختلفـى از سـلامتى داشـته باشد[؟]. يويايى و تحولات سريع در جوامع، فضاى زندگى انسان وعوامل تاثير كذار بر آن تحولات تكنولوزيكى، سلامت سـالمندان را نيز دجار تغيير كرده اسـت. انـدازهخيــى سـلامت درك شـده سالمندان يك شاخص جهانى و مفيد براى سطح سـلامت آنـان است و با عناصر بيولوزيكى و اجتمـاعى آن در تعامـل اسـت. در حقيقت سنجش سطح سلامت درى شده يكى از رايجترين انواع تعيين وضعيت سلامت در سالمندان از ديدكاه ذهنى مىباشد زيرا مىتواند جنبه هاى مختلف سلامتى را بررسى كند. سلامت درى شده به نوعى به جنبه هاى مختلف سلامتى كه توسـط سـازمان بهداشت جهانى توصيه شده است توجه مى كند[س]. بر آورد مىشود كه در سطح جهان سهم جمعيت سـالمندان •ع سـال و بـالاتر در

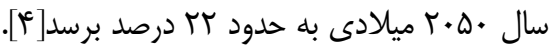


باشد[• [1]. سولا و همكاران به بررسى ارتبـاط رفتارهـاى ارتقـاء دهنده سلامت با سطح فعاليتهاى روزمره زندگى و فعاليتهـاى روزمره زندگى با ابزار در سالمندان غرب تهران يرداختند كه نتـايج نشان داد بين رفتارهاى ارتقــاء دهنـــه سـلامت و سـلامت رابطـهـه معنى دارى وجود داشت[ [1]. لوكاس و همكـاران در مطالعـه ايسى عوامل موثر بر رفتارهاى ارتقاءدهنده سلامت بر زنان هو سـال بــــ بالا نشان داد بين سن، وضعيت تاهل، نزاد، تحصيلات و اعتماد به نفس با رفتارهاى اتقاء دهندهى سلامت رابطـهـه معنى دارى وجـود دارد[1 I ]. بالجانى و همكاران در يزوهشى نشان دادنــ كـه سـن و تحصيلات با خودارزيابى سـلامت رابطـهـ معنسىدارى دارد[سا1]. در اين يزوهش تلاش شـده اسـت كـهـ رابطـهـ متغيرهـاى جمعيتـى، اجتماعى و فرهنگى با خودارزيابى سلامت سالمندان بررسى شود.

\section{مواد و روش ها}

مطالعه حاضر، مطالعه اى توصيفى- تحليلى بـود كـهـ بـه صـورت مقطعى در بازه زمانى اسفند تا ارديبهشت در سـال عوجا انجـام شد. جامعه آمارى اين تحقيق را افراد سالمند بالاى هو سال ساكن شهر شيراز و ياسوج تشكيل داده بودند. بـراى گَردآورى داده هـا، • • نفر از سالمندان در شهر شيراز و ياسوج به شيوه نمونهَيـرى خوشهاى جنـد مرحله ايى انتخـاب شـدند. ابتـدا در شـهر شـيراز تعداد جمعيت 90 سـال بــه بــالا بــر اسـاس منــاطق 9 كانــهـ شهردارى شهر شيراز در سر شـمارى • وجسا مشـخص شـد. بعد از مشخص شدن تعداد نمونه در هر كدام از مناطق شهر به صورت تصـادفى در هـر محلـهاى انتخــاب شـد. در درون
يكى از هدفهاى مهم نظام سلامت در هر كشور تـأمين، حفظظ و ارتقا، سلامت و كيفيت زندگى تمام افراد جامعه است. براى تحقق اين امر مهيا سازى امكانات و تسـهيلات مناسـب جهـت تـأمين سلامت جسمى، روانى و اجتماعى انسان در كليه مراحل زندگى از جمله حقوق اوليه بـه شــمار مسىود. سـازمان بهداشـت جهـانى، سلامتى را حالت بهزيستى كامل جسمانى، روانى و اجتمـاعى و نــهـ. فقط فقدان بيمارى يا ناتوانى مى داند[^]. بـه طـور كلى تعـاريف

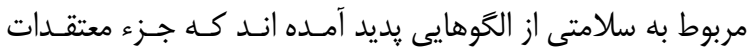
دانشمندان مختلف بوده اند. بر اساس اين اعتقادات سه الكوى عمده در تعريف سلامتى همواره مد نظر بوده است: الكُوى يزشكى: ايـن الخو عمدتاً بر تبيين زيست شناختى و فيزيولـوزيكى سـلامتى مسى يردازد. الخَوى محيطى: در اين الحَـو سـلامتى بـر حسـب كيفيـت سازش فرد با محيط به هنخــام تغييـر شـرايط تعريـف شـــه اسـت. الكَوى كلى نكَّر: اين الكَو سلامتى را بر حسب جنبه هـاى زيسـت شناختى، فيزيولوزيكى، روانى، هيجانى، اجتماعى، معنوى و محيطى افراد را شامل مى شود و بر سلامتى بهينه، يِيشيَى از بيمـارى و حالت هاى روانسى و هيجـانى مثبـت متمركـز اســ[9]. مطالعـات متعددى در زمينه سلامت سالمندان انجام شـده اسـت بـهـ عنـوان نمونه مىتوان يه اين مطالعات اشاره كـرد، معتمــى شـلمزارى و همكـاران در يزوهشـى بــهـ بررسى نقـش حمايـت اجتمـاعى در رضايتمندى از زندحى، سلامت عمومى و احساس تنهايى در بـين سالمندان شهركرد يرداختند كه نتايج مطالعه شـان نشـان داد بـين انواع حمايت اجتماعى با سلامت عمومى همبسـتخى وجـود دارد و ميزان همبستخى بعد حمايت عاطفى بيش از حمايت ابـزارى مسى- 


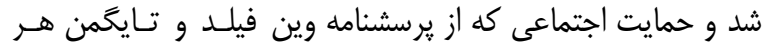
كدام با ^ سوال، بخش ششم سوالات مربوط به ارتباط و صميميت با فرزنــدان بـا و سـوال بـود. بخـش هفـتم سـوالات مربـوط بـهـ خودارزيابى سـلامت در جهـار بعـد سـامت جسـمانى، اضـطراب، افسردگى و كاركرد اجتماعى با r سوال بود.كويههاى برسشـنامه خودارزيابى سلامت با استفاده از مقياس ه تايى ليكرت امتيـازدهى شد. به اين شكل كه امتياز يك تا پنج به ترتيب نشان دهنده نمره

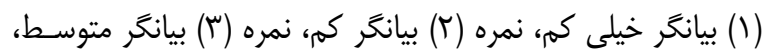
نمره (أ) بيانكر زياد و نمره (ه) بيـانغر خيلـى زيـاد بودنـــ. پايـايى

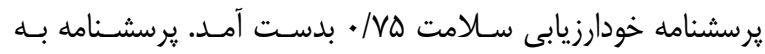
صورت پايلوت بر روى هـ نفر از جامعه آمارى، مورد آزمـون قـرار كرفت و منجر به برخى بازنخرى ها در برسشنامه، نظير حذف برخى از تويه ها و اصلاح نحوه و طراحى برخى از يرسـشهـا ترديسـ. براى تعيين اعتبار يرسشنامهها ازاعتبـار صـورى و محتـوا اسـتفاده شدكه براى تعيين اعتبار صورى تعدادى برسشـنامه بــه سـالمندان ارائه گرديد و براى اعتبار محتوا، يرسشنامهدر اختيار اعضاى هيـأت علمى رشـته جامعـه شناسـى و جمعيـت شناسـى دانشـكده علـوم اجتماعى دانشگاه شيراز قرار كرفت و بعـــ از جمـع كـردن نظـرات آنها،اصلاحات لازم بر اساس باز خورد كسب شده صورت كرفت. آلفاى كرونباخ به ترتيب براى رفتارهاى سلامت، حمايت اجتمـاعى

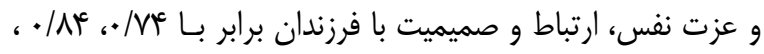

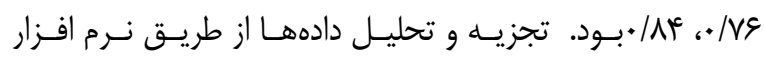
آمارى SPSS نسخه •r در دو سطح آمار توصيفى نظير فراوانى، ميانخين و انحراف معيـار و در سـطح آمـار تحليلى نظيــر آزمـون همبستخى ييرسون و ركرسيون انجام يذيرفت. براى برآورد ميـزان
محلهها به شـيوه تصـادفى سيسـتماتيك نمونـهـ مـورد نظـر انتخاب و با او مصاحبه به عمل آمـد. بــراى نمونـهَكيـرى در شهر ياسوج، ابتدا شـهر ياسـوج بـهـ جهــار منطقـه تقسـيم و سيس در درون اين جهار منطقه، مناطقى به صورت تصادفى انتخاب شدند و در هر منطقه تعداد يرسشنامههاى مشـخص ير شد. مشاركت كليه شركت كنندكان در اين يزوهش داوطلبانه و بارضايت آكاهانه و از طريق مراجعه به درب منازل انجام يـذيرفت. براى اندازه كَيرى عزت نفس از يرسشنامه عزت نفس ده سـالى

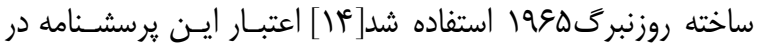
مطالعات ديگر از طريق ضريب همبستخى تاييـد شـده اسـ[10] ״ايايى اين برسشنامه از طريق آلفاى كرونباخ در اين تحقيق V9/. بدست آمد. اعتبار برسشنامه حمايت اجتماعى وين فيلد و تايخمن در مطالعات ديخر با روش اعتبار محتوا تأييد شـده اسـت [ع]] در اين مطالعه پِايايى برسشنامه با آلفا كرونبـاخ ^^// محاسـبه شــ. بخش اول سوالات مربوط به ويزَيَهاى دموكَرافيك شـامل (سـن، تحصيلات، طبقه اقتصـادى- اجتمـاعى، وضـعيت اشـتغال) طبقـهـ اقتصادى - اجتماعى بر اساس وضعيت درآمد سنجيده شـد، بخـش دوم سوالات مربوط به سابقه بيمارى با 1 سوال در مورد (فشارخون بالا، سابقه سكته قلبى، بيمارى قند، جربى خـون، انـواع سـرطان، مصرف دخانيات، جـاقى، بيمـارى اعصـاب و روان )، بخـش سـوم سوالات مربوط به رفتار سـلامت شـامل خـوردن غـذاى مناسـب، ورزش كردن، يرهيز از غذاى خرب و مواردى از ايـن قبيـل بـا سوال. سوالات بخش اول خود ساخته بود و بخش هاى دوم به بعد را از يرسش نامه هاى استاندارد استفاده شد. بخش جهارم و پـنجم سوالات مربوط به عزت نفس كه از يرسشنامه روزنبـرى استفاده 
نشان داديم كه سه بخـش اول ايـن نظريـها بــه بررسـى وضـعيت

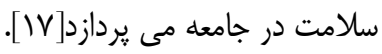

يافته ها

همانكَونه كه در جـدول (، مشـاهده مسىشـود مشخصـات فـردى

پاسخكَويان آورده شده است. در اين يزوهش تمام ياسخكويان مـا

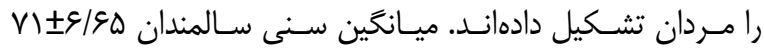

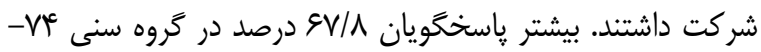

هو قرار داشتند و تنها // درصـد از ياسـخكويان در گَروه سـنى

ه9+ قـرار داشـتند. //او درصـد از پاسـخحكويان سـابقه بيمـارى

داشتند. از افراد نمونه مورد بررسى در مورد تعلق طبقـاتى و اينكـهـ

خود را جزو كدام طبقه اجتماعى - اقتصادى مى دانتــــــوال شـــ.

كمترين درصد يعنى حدود ك/ F درصد از افـراد خـود را متعلق بـهـ

طبقه بالا اعلام كردند؛ بيشترين درصد يعنى ع/ع درصد از افـراد

خود را متعلق به طبقه متوسط اعلام كردنـد، توزيـع نمونسه مـورد

بررسى بر اساس ميزان تحصيلات نشان داد كـهـ بيشـترين درصـــ

F F/a درصد از افراد دييلهم و زير دييلهم بوده است.

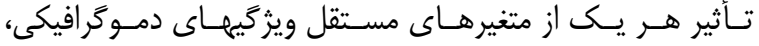

رفتارهاى سلامت، عـزت نفـس و حمايـت اجتمـاعى و رفتارهـاى

سلامت از مدل ركرسيون خطى خُند متغيره اسـتفاده شـــ. بـراى

بررسى تاثيرات جمعى و مستقل متغيرهاى مستقل بر متغير وابسته

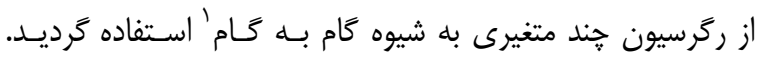

ركرسيون جند متغيره به روش كام به كام، آمارههـاى مربـوط بــــ

تبيين متغير وابسته (خودارزيابى سلامت) را براساس يـى سـرى

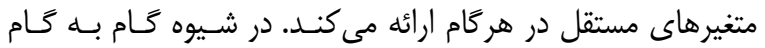

متغيرها يك به يك به مدل وارد مى شوند يعنى ابتدا متغيرى كـه

بيشترين همبستخى را با متغير وابسته دارد مشخص مى شـود .در

اين تحقيق از الكوى يرسيد-يروسيد ستفاده شد. اين الخَـو عوامـل

اجتماعى و فرهنكَى و حتى جمعيتى موثر بـر سـامت را در قالـب

سه دسته عوامل مساعدكننده، قادر كننده و تقويـت كنــده تقسـيم

بندى كرده است. عوامل مساعد كننده همان دانش ها، نحَرش ها،

باورهـا، ترجيهـات فـردى اسـت. هــر كــدام از ايـن متغيرهـاى

مساعدكننده، موجب بروز رفتارى خاص در فرد مسىشـود. عوامـل

قادركننده با تاثير غيرمستقيه بر عوامل محيطى بر رفتار تاثير مى

كذارند. اين دسته از عوامل، فرد را قادر مىسـازد تـا از محـيط بــهـ

كونهاى خاص استفاده كند و فرد را در جايخاهى قرار مىدهد كه از

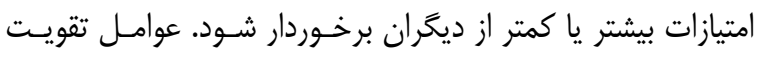

كننده آن دسته عواملى است كه بعد از انجـام يـــ رفتـار حضـور

دارند و باعث انخيزه براى تداوم آن خواهند شد. نتايج تحقيق را در

استفاده از سه بخش اول نظريه يرسيد- يروسيد در نتيجـه كيـرى

1.Stepwise 
جدول شماره ا. مشخصات فردى - اجتماعى ياسخكَويان در طبقات مختلف متغيرها و مقدار p-value در ارتباط با خودارزيابى سلامت

\begin{tabular}{|c|c|c|c|c|c|}
\hline p-value & فراوانى(درصد) & متغير & p-value & فراوانى(درصد) & متغير \\
\hline & & طبقه اقتصادى اجتماعح & & & سن* \\
\hline \multirow{4}{*}{$+1++$} & $18(F / T)$ & بالا & $.1 . .9$ & ITr (gr/A) & $8 \Delta-V^{c}$ \\
\hline & 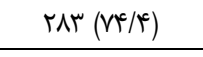 & متوسط & & $p q(r V / r)$ & $V \Delta-\Lambda F$ \\
\hline & $V V(r \cdot / r)$ & يايين & & $V(\Gamma / q)$ & $\Lambda \Delta-q \uparrow$ \\
\hline & & تحصيلات* & & $r(1 / 1)$ & +90 \\
\hline \multirow[t]{5}{*}{$+1+14$} & $|f|(r V / I)$ & بـ سواد & & & سابقه بيمارى * \\
\hline & 114 (FV/q) & دييلم و زير دييلم & 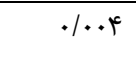 & (q)/I) & دارند \\
\hline & $1 \Lambda(F / V)$ & فوق دييلم & & & \\
\hline & $r V(V / I)$ & ليسانس & & If^ (พN/q) & 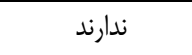 \\
\hline & $9(T / 4)$ & فوق ليسانس و بالاتر & & & \\
\hline
\end{tabular}

(فاقد معنادارى) = N.S***

(اس/Fr درصد) همجنين در شهر ياسوج هم بيشترين نمره مربـوط

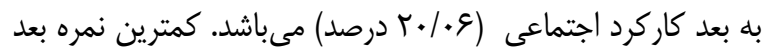

سلامت در شهر شيراز مربوط به سلامت جسمانى (سب/عادرصد) و

در شهر ياسوج هم مربوط به بعد سلامت جسمانى (Tس/هادرصـد)

مى باشد. p-value $<0 / 005^{*}$
به طور كلى ميانكَين نمرات خودارزيابى سلامت نمونه مورد مطالعه VV/·V بدست آمد. اين مقياس خود به جهرار زير مقيـاس سـلامت جسمانى، اضطراب، كاركرد اجتماعى و افسردگى تقسيم مسىشـود. اطلاعات مربوط به هر زير مقيـاس در جـدول نشـان داده شـده است. همانگخونه كه مشـاهده مسىشـود بطـور كلى بيشـترين نمـره

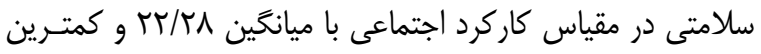
نمره سلامتى در مقياس سلامت جسمانى با ميـانخين سر/\& مسى باشد. در شهر شيراز بيشترين نمره مربوط به بعد كاركرد اجتماعى

جدول شمارهץ، آماره هاى توصيفى براى نمره مقياس خود ارزيابى سلامت

\begin{tabular}{|c|c|c|c|c|c|c|}
\hline \multirow{2}{*}{ خودارزيابى كلى مقياس } & \multicolumn{4}{|c|}{ نمره زير مقياس ها } & \multirow[t]{2}{*}{ آماره هاى توصيفى } & \\
\hline & افسردخى & كاركرد اجتماعى & اضطراب & سلامت جسمانى & & \\
\hline$V r / r r \pm) \varepsilon / r q$ & 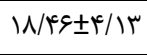 & $r \cdot / \cdot q \pm \Delta / \cdot \cdot$ & $19 / Y \Psi \pm \Delta / F V$ & $\mid Q / T_{T \pm Y / \Lambda}$ & ميانگين و انحراف معيار & ياسوج \\
\hline$\Lambda+|\varepsilon \bigvee \pm| \varepsilon / \Lambda \Lambda$ & 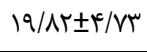 & $\Gamma \digamma / \mu I \pm T / 9 D$ & $19 / r \cdot \pm \Delta / v \cdot$ & $|V / r \Psi \pm \Delta /|$ & ميانخين و انحراف معيار & 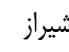 \\
\hline$V V /+V \pm 10 /+r$ & $19 / v \pm F / \Delta$ & $r Y / r \Lambda \pm r / q \Delta$ & $19 / r T \pm \Delta / \Delta 9$ & $\mid \varepsilon / \mu r \pm \Delta / 1$ & ميانگَين و انحراف معيار & 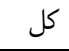 \\
\hline r & $\Delta$ & $\varepsilon$ & $\varepsilon$ & $\Delta$ & تعداد گويه & \\
\hline
\end{tabular}

با متغير وابسته (خودارزيابى سلامت) و تمامى ابعاد آن نشان مسىدهد. بين رفتار سلامت و تمامى ابعاد خودارزيابى سـلامت، رابطـهـ
جدول شماره ऍ، ضريب همبستخى و معنى دارى متغيرهاى عـزت نفس، حمايت اجتماعى، رفتار هاى سلامت و ارتباط با فرزنـدان را 
حمايت اجتماعى و خودارزيابى سلامت نشـان مسىدهـد كـه بـين

حمايت اجتماعى و تمام ابعاد خودارزيابى سلامت رابطه معنىدارى

وجود دارد. يعنى با افزايش حمايت اجتماعى، خودارزيـابى سـامت

افزايش مىيابد.
معنى دارى وجود دارد. همانگَونه كه در جــدول شـماره س مشـاهده مىشود، رابطه معنى دار مستقيم بين عزت نفـس و خـود ارزيـابى سلامت وجود دارد. با افزايش عزت نفس، خودارزيابى سلامت فرد افزايش مى يابد. عزت نفس با خودارزيابى سلامت همبستخى قوى دارد. نتايج ضريب همبستخى بيرسـون بـراى بررسـى رابطـه بـين

جدول شماره س، آزمون رابطه متغيرهاى فرهنكى - اجتماعى با خود ارزيابى سلامت

\begin{tabular}{|c|c|c|c|c|c|c|}
\hline افسردَى & كاركرد اجتماعى & اضطراب & سلامت & خودارزيابى سلامت & \multicolumn{2}{|c|}{ متغيرهاى مستقل } \\
\hline . /TFA & .11 .9 &.$/ 1 \% \Delta$ & .1 .99 &.$/ 194$ & ضريب همبستكى & ارتباط با \\
\hline $.1 . .1$ & .1 .19 & $.1 \cdots 1$ &.$/ 4$. &.$/ .1 \mathrm{~V}$ & $\mathrm{p}$-value & فرزندان \\
\hline . IFeg & . &.$/ T Y V$ & $.1 \cdot 40$ &.$/ T \Delta Q$ & ضريب همبستكى & حمايت \\
\hline.$/ \cdots$ & $.1 \cdots$ & $.1 \cdots$ & m & $.1 \cdots$ & $\mathrm{p}$-value & \\
\hline .1109 & $\cdot / 1 \cdot V$ & $\cdot / T \cdot V$ & .1 .91 & $\cdot / 4 \cdot 9$ & ضريب همبستكى & رفتارهاى \\
\hline.$/ . r$ &.$/ \cdot \mu$ &.$/ \cdots$ &.$/ \cdot 14$ & $.1 \cdots$ & $\mathrm{p}$-value & سلامت \\
\hline.$/ \Delta \wedge \Delta$ & ه מז/. & ./FVT &.$/ 498$ &.$/ \Delta F q$ & ضريب همبستكى & عزت نفس \\
\hline.$/ \ldots$ &.$/ \ldots$ &.$/ \ldots$ &.$/ \ldots$ &.$/ \ldots$ & $\mathrm{p}$-value & \\
\hline
\end{tabular}

خودارزيابى سلامت دارد. به گونه ايى كه با داشتن سـابقه بيمـارى خودارزيــــابـى ســــلامت در افــــراد كــــاهش يافتـــــه اســــت
جدول شمارهأ، رابطه ميان سابقه بيمارى و خودارزيابى سـلامت را

نشان مى دهد. سابقه بيمارى داراى رابطه معنى دار و معكوسـى بـا

جدولع، آزمون رَّرسيون تك متغيره ميان سابقه بيمارى و خودارزيابى سلامت

\begin{tabular}{|c|c|c|c|c|c|c|c|c|}
\hline \multirow{2}{*}{$\begin{array}{c}\text { Adjusted } \\
\mathbf{R} \\
\text { Square }\end{array}$} & \multirow{2}{*}{$\begin{array}{c}\mathbf{R} \\
\text { Square }\end{array}$} & \multirow{2}{*}{ سطح } & \multirow{2}{*}{$\begin{array}{r}\text { مقدار } \\
\text { T }\end{array}$} & \multirow{2}{*}{$\begin{array}{c}\text { ضرايب } \\
\text { شداندارد } \\
\text { Beta } \\
\end{array}$} & \multicolumn{2}{|c|}{ ضرايب استاندارد نشده } & \multirow{4}{*}{ سابقه } & \multirow[t]{2}{*}{ شهر } \\
\hline & & & & & Std.Error & B & & \\
\hline .1 .9 & .1 .90 & $\cdot 1 \ldots$ & $-F / F F$ & $-\cdot / \pi \cdot 1$ & - /AVq & $-r / q$. & & شيراز \\
\hline $.1 \cdot r q$ & מש & .1 .19 & س &.$- / 1 \wedge \varepsilon$ & $\cdot \mid \Lambda \& \Lambda$ & $-r / I I$ & & ياسوج \\
\hline $.1 .+49$ & $.1 \cdot \Delta r$ & $.1 \ldots$ & $-F / 4$ & -ITHA &. $\mid 94$. & $-r / A r$ & & كل \\
\hline
\end{tabular}




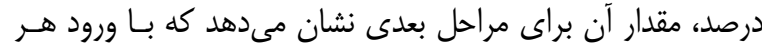

متغيير به معادله رگر سيون در هـر كـدام از مراحـل هنـــ درصـد از

تغييرات متغير وابسته تبيـين شـده اسـت. در مرحلـه دوم بـا ورود

متغيير رفتارهاى سلامت، اع/ • درصد به مقدار تبيين افزوده شـده

است. در مرحله سوم با ورود متغيير سابقه بيمارى، اس// درصد به

مقدار تبيين افزوده شده است. سهم نسـبى هـر متغيـر مسـتقل در

مدل مشخص شده است. همانغونه كه مشخص است متغير عـزت

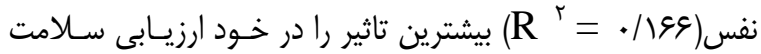

مردان سالمندان دارا مى باشد.

براى بررسى تاثيرات جمعى و مستقل متغيرهاى مستقل بـر متغيـر

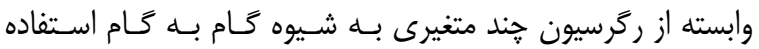
كرديم. در شيوه كَام به كام متغيرها يك به يك به مـدل وارد مسى شوند. يعنى ابتدا متغيرى كه بيشترين همبستخى را با متغير وابسته دارد، انتخاب مى شود. دومين متغيرى كه وارد تحليـل مسى شـود، متغيرى اسـت كـهـ يـس از تفكيـك متغيـر مقـدم بـر آن، موجـب بيشترين افزايش در مقدار ضريب تعيين ( R مى شود و اين كـار تا زمانى ادامه مى يابد كه خطاى آزمون معنـى دارى بــه ه درصـد برسد[11]]. همانگگونه كه در جدول شـماره ه، مشـاهده مـى شـود مقدار R براى متغيير عزت نفس در كام اول برابر است با وع||.

جدول 0، آماره هاى ارزيابى مدل هاى رتر سيونى برآورد شاخص خودارزيابى سلامت براساس عوامل اجتماعى- جمعيتى مدرلى

\begin{tabular}{|c|c|c|c|c|c|c|c|}
\hline p-value & $\begin{array}{c}\text { مقدار } \\
\text { F }\end{array}$ & 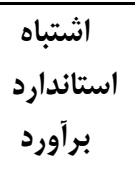 & $\begin{array}{c}\text { تغييرات } \\
\text { R }\end{array}$ & ضريب & $\begin{array}{c}\text { مقدار } \\
\text { R }\end{array}$ & مانغيرهاى داقى مدل & مراحل \\
\hline $.1 \ldots$ & $r q / 9 r$ & $|r / 4|$ &.$|19|$ & .1199 & $\cdot / 4 \cdot 1$ & عزت نفس & 1 \\
\hline.$/ \ldots$ & $M / \Lambda F$ & $11 / 99$ & $. / Y \mid S$ & . ITH & . IFV & رفتارهاى سلامت & $r$ \\
\hline $.1 \ldots$ & $\mathrm{IV} / \mathrm{IV}$ & $11 / \mathrm{r}$ & שוא/ &.$/ T \Delta \Lambda$ & $\cdot / \Delta \cdot 1$ & سابقه بيمارى & r \\
\hline
\end{tabular}

\section{بحث و نتيجه تيرى}

را ييش بينى و زمينه مناسـبى را بـراى برنامـهـ ريـزان و تصـميم گَيرندًان حوزه سالمندى فراهم كنند. بدون ترديد، ايـن موضـوع توجه بيشـتر متغيرهـاى زمينـهـ اى را در جهـت توانمندسـازى و يويايى زندگى سالمندان مى طلبـد. مـدل، الخـو يرسـيد- يروسـيد عوامل اجتماعى و فرهنگى و حتى جمعيتى موثر بر سـلامت را در قالب سه دسته عوامـل مســاعدكننده، قادركنـــده و تقويـت كنتـده تقسيم بندى كرده است. اين مطالب نتايج تحقيق را در استفاده از
بهتر آن است كه در ارزيـابى وضـعيت سـلامت سـالمندان عـزت نفس ، منابع حمايتى و سابقه بيمارى آنها به عنوان عوامل مرتبط با وضعيت سلامت مورد بررسى قرار گيرد. با توجه به يافته هاى حاصل از اين تحقيق، متغيرهاى جمعيت شناختى مى توانند هـم ارز ديخر متغيرهاى فرهنگى و اجتماعى وضعيت سلامت سالمندان 
بخذارد. بر اساس (جدول شماره َ) بين عزت نفس و خودارزيـابى سلامت رابطه معنىدارى يافت شد كه بـا نتـايج تحقيـق لوكـاس

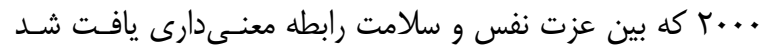
همسو مىباشد[ب] [1]. افزايش عزت بنفس در افراد سالمند مىتوانــــ در درك ذهنى آنها در مورد سلامتشان تـاثير بحــارد. نتـايج ايـنـ تحقيـق بـر اسـاس (جـدول شــماره ع) حـاكى از رابطـهـ معنسدار معكوس بين بيمارى و خودارزيابى سلامت است، يعنى با افزايش

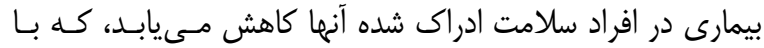
نتايج تحقيق وى يو و همكاران (سا +r) كه نشان داد شـيوع تمـام بيمارى ها با خودارزيابى سلامت بإيين همـراه اسـت همسـو مسىباشد • ·r]. فرد بيمار سلامت خود را در سـطح يـايين مسىدانـد. بـا استفاده از يرسشنامه وين فيلد و تايخمن و (جدول شـماره ؟) ايـن نتيجه مشخص شد كه بين حمايت اجتماعى و خودارزيابى سلامت رابطه معنىدارى وجود دارد، كه با نتايج تحقيق معتمدى شلمزارى

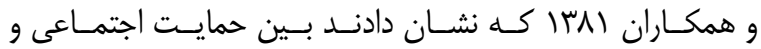
خودارزيابى سـلامت رابطـهـه معنــدارى وجـود دارد، همسـو مسىباشد • [1]. حمايت اجتماعى مىتوانـــ شـرايط و دورهى سـالمندى مناسبى را براى سالمندان فراهم كند. با توجه به تاثيرى كه عـزت نفس در خودارزيابى سلامت، سالمندان دارد و عـزت نفـس يـايين مى تواند با نوعى خود كم بينى در فرد همـراه باشـــ و اينكـهـ فـرد نسبت به خود خه احساسى داشته باشـــ و بـــاى خـود جـهـ ميـزان ارزش و اهميت بداند، مىتواند بر خودارزيابى سلامت تاثير بحذارد، بايد از طريق بركزارى كلاسها به افزايش عـزت نفس و اعتمـاد بنفس افراد سالمند كمك كرد. با توجه بـه مهـهم بـودن رفتارهـاى سلامت كه در يافته ها نيز تاييد شد، توجه بيشتر بـه برنامـهــيى
سه بخش اول نظريه يرسيد- يروسـيد نشـان داد كـه بـهـ بررسىى وضعيت سلامت در جامعه و عوامل موثر بر آن مسىيـردازد. بــدين ترتيب نشان داده شـــ كـه عوامـل اجتمـاعى و فرهنخـى و حتـى جمعيتى بر خودارزيابى سلامت سالمندان تـاثير دارد و ايـن نشـان دهندهى اين است كه سلامتى ضـمن يـك يديــده يزشـكى يــ يديده اجتماعى است. ميانگَين خودارزيابى سلامت ميان سـالمندان شهر شيراز بالاتر از شهر ياسـوج بـود(جـدول شــماره ؟). در ايـن

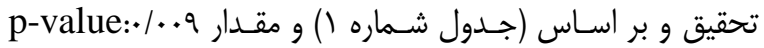
مشخص شد متغير سن با سلامت ادراك شده رابطه معنسدار دارد

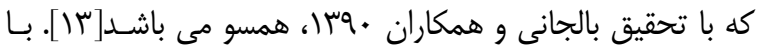
افزايش سن از سلامت جسمانى سـالمندان كاسـته مســـود. بـر اساس (جدول شـمارهl) و مقـدار ..." p-value: مشـخص شـد خودارزيابى سلامت با طبقه اقتصادى-اجتماعى رابطهـه معنىدارى

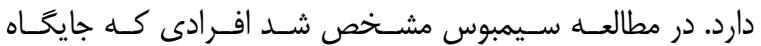
اقتصادى- اجتماعى پايينى دارند، در همه ابعاد سلامت نيز وضعيت بدترى دارند[19] كه همسو با اين تحقيق مىباشد. سالمندانى كـه طبقه اقتصادى- اجتماعى بايينى دارند مى توانند از لحاظ سـلامت جسمانى در سطح يايين ترى باشند، ميزان افسردگى و اضطراب به دليل شرايط اقتصادى پايين بيشتر مى شود و ممكن است كـاركرد اجتماعى ضعيف ترى ارائه دهنـــ. بـين تحصـيلات و خودارزيـابى سلامت رابطه معنىدارى يافت شد بر اساس (جـدول شـماره () و مقدار rp-value:- كه با نتـايج تحقيـق بالجـانى و همكـاران . وسا كه بين تحصيلات و سلامت رابطـهـه معنــدارى يافت شـــ همسو مىباشد[با]. تحصيلات موجب افزايش آَاهى افـراد مسىشود و اين افزايش آكاهى به نوبهى خود مىتواند بر سلامت تـاثير 


$$
\begin{aligned}
& \text { براى ارتقاى سلامت و توجه به آموزش به افراد سـالمند از طريـق عدم انزواى سـالمندان، جمعيـت سـالمند بـا انـزوا و كـم تـوانى و } \\
& \text { رسانهها براى جلـوگيرى از مشـكلات مـزمن در دوران سـالمندى بيمارىهاى مزمن همراه است و نياز به حمايتهاى اجتماعى دارد. }
\end{aligned}
$$

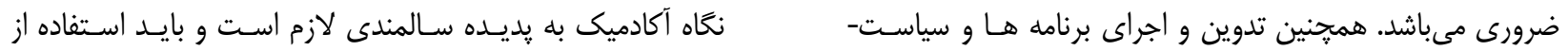

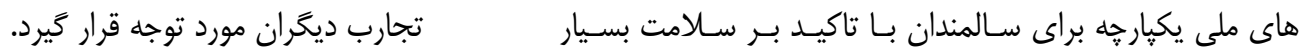

$$
\begin{aligned}
& \text { ضرورى اسـت. بـا توجـهـ بـه تـاثيرى كـه حمايـت اجتمـاعى بـر } \\
& \text { خودارزيابى سلامت سـالمندان دارد، توجـهـ بـه انـواع شـبكههـاى تشكر و قدردانى } \\
& \text { حمايت اجتماعى مانند حمايت ابزارى، عاطفى بستخى به شـرايط و از كليه سالمندان كه با صبر و حوصله ما را در انجام ايـن تحقيـق } \\
& \text { موقعيت فرد سالمند مهم مىباشد. توجه به نياز عاطفى و مراقتتى يارى نمودند تشكر به عمل مى آيد. اين مقاله بركرفته از بايان نامه }
\end{aligned}
$$

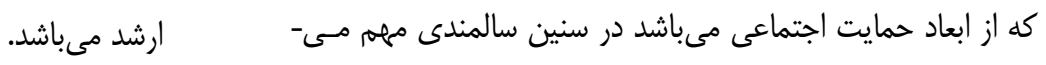

$$
\begin{aligned}
& \text { باشد. بنابراين بايد برَزارى كلاسهايى براى خانوادههـا در مـورد } \\
& \text { نحوه حمايت و نيازهاى سالمندان بركزار شود. برنامـهريـزى بـراى }
\end{aligned}
$$

- References

1- Ministry of Health and Medical Education, Estimate life expectancy and predict the population of Iran, Tehran: 2006.

2- Rob B, Public Health Policy and Politics, London: Mac Millan press: 2000.

3- Geneva W, World Health Organization: The Ottawa charter for health promotion, Journal Health Promotion 1986; (1):1-4.

4-United Nation, World Population Ageing, Population division, UN: New York: 2007.

5- Sadeghi R, the Iranian population changes: past, present and future. Research report, Tehran: Center for Statistics: 2011. (Persian)

6- Hatami H, public health, Tehran: Arjmand Publishers: 2004. (Persian)

7- Saifzade A, characterized by economic, social, demographic and mental health Old: The Case study of the Azarshar, Journal of Population 2009; (64-63): 127-162. (Persian)

8- Sabbagh S, Moeinian N, Sabbagh S, measure social health and social factors associated with it among households in the city of Tabriz. Sociological studies 2013; 3(1): 27-44. (Persian) 
9- Herman $\mathrm{H}$, identify the effect of communicational conflict resolution and problem-solving strategies to students' psychological health. Smynar Third overall mental health of students 1999.

10- Motamede Sh, Javadajeh A, AzadFallah P, Kiamanesh A, The social support on life satisfaction, general health and loneliness among the elderly over 60 years, Psychology 1381; (1):115-133. (Persian)

11- Sulla A, Habibi S, Nikpour M, Rezaei H, Haqqani, Relationship between health promotion behaviors with the activities of daily living and activities of daily living in elderly with tools West of Tehran, Iranian Journal of Ageing, second, fifth edition 2002: 339-332. (Persian)

12- Lucas JA, Orshan SA, Cook F, Determinants of health-promoting behavior among women ages 65 and above living in the community ,US National Library of Medicine National Institutes of Health 2000; 14 (1): 77-100.

13- Baljany E,Salari Sh, Salimi S, Safari E, Alavi S, Abdollahi S ,early health promotion behaviors and cancer screening in elderly Orumieh, Orumieh Medical Journal 2010; 21(2): 217223. (Persian)

14- Asadi Gandomani R, Tymorzadeh L. the relationship between self-esteem and depression Tymvrzadh 1393. jokes with satisfaction with body image in teen girls, Journal of Futures Studies Management 2013; 20 (100): 13-21. (Persian)

15- Borna M, Savari K. Its simple and multiple self-esteem, loneliness, assertiveness, shyness, new findings in psychology 2010; 5(17): 53-62. (Persian)

16- Abbasi Azar F, Ahmadi M, Shams J,Abadi A. The effect kangaroo mother care in the postpartum blues. Journal of School of Nursing and Midwifery, Beheshti University of Medical Sciences and Health Services 2012; 23 (80): 74. 83. (Persian)

17- Meshki M. Review of the use of Precede-Proceed Model combining health locus of control theory to enhance the mental health of students. PhD thesis, Health Education, Faculty of Medical Sciences, Tarbiat Modarres University 2006. (Persian)

18- Habibpour c, Safari R, Comprehensive guide spss application, chap second in survey research, second edition, Tehran, Motefakeran Publishing 2012; 481. (Persian)

19-Tsimbos, C. An assessment of socio-economic inequalities in health among elderly in Greece, Italy and Spain.Jornal Public Health 2010; 55(1):5-15.

20- Wu Sh, Wang R, Zhao Y, Ma X, Wu M, Yan X, Jia H . The relationship between selfrated health and objective health status: a Population-based study. BMC Public Health 2013;13(320):1-9. 